Khartoum, through customs at Sana'a airport. But annual imports have perhaps halved since 2008 , to c. $25 \mathrm{~kg}$ of rhino horn in 2012. Yemen cannot compete with the higher prices offered in eastern Asia. Yemen's wholesale price for horn has remained stable since 2008 at USD 1,500 per kg. The leftover shavings sell illegally in Sana'a for USD 940 per kg, for the eastern Asian market. Vietnam and China are experiencing an economic boom, stimulating demand for the horn.

Yemen's economic crisis resulted in some Yemenis selling their valuable daggers with rhino horn handles, to pay for air passages to leave the country or simply to feed their families. Only the rich can now afford new rhino horn handles for their daggers and, unlike the former President, the new incumbent does not wear a jambiya. Moreover, many Yemenis in Sana'a no longer want to wear an expensive dagger on the street, for fear of it being stolen.

To help further reduce demand for new rhino horn, we produced billboards, banners, posters and stickers about the plight of the rhino. We posted these in the Sana'a zoo, and elsewhere in the city, including in shop windows and taxis. Apart from hostility from some sellers of rhino horn daggers in the souq, Yemenis welcomed us warmly, and were sympathetic.

With new rhino horn daggers less popular, Yemenis have been developing an alternative material for handles that is inexpensive yet closely resembles rhino horn. The handles are made of a gum with a mystery additive that looks like the grain seen in a rhino horn handle. This handle was first introduced in 2008, initially in China, we were told, and has been steadily improved by artisans in the Sana'a souq. Some Yemenis who will not wear cheap daggers with water buffalo horn handles (which are most commonly made) are happy to wear these new so-called Chinese daggers. Many people in Sana'a mistakenly believe they are still imported from China but they are actually being crafted in the souq, bringing much needed employment to artisans.

The time is ripe to expand the marketing of the new jambiya. We spoke with journalists in Sana'a who agreed that these new daggers need to be publicized with a more alluring name: dragon's horn (qarn al tinnin) has been recommended as it conjures up images of mystery, legend and power combined. Let us hope it catches on in a country ready to move on, with Yemenis seeking change and improvement in multiple ways.

LUCYVIGNE and ESMOND MARTIN Nairobi, Kenya. E-mail rhino@ wananchi.com

\section{Rediscovery of the supposedly extinct Dipterocarpus cinereus}

Trees of the family Dipterocarpaceae are valued for their timber and resin. In Sumatra the family is represented by eight genera and c. 109 species and six subspecies, of which at least 11 species are endemic. One of these endemics, Dipterocarpus cinereus Sloot., was categorized as Extinct on the IUCN Red List in 1998. According to Ashton (Dipterocarpaceae. Flora Malesiana, Series I, 92, 237-552) this species is only known from the c. 8,00o ha Mursala (= Morsala, Moesala or Mansalaar) Island in the District of Tapanuli Tengah in North Sumatra Province. It was first collected in 1916 by A.V. Theunissen and described by Dirk Fok van Slooten under the name Dipterocarpus cinerea in 1927. In 1982 Peter Ashton asserted its name to be Dipterocarpus cinereus Sloot.

With the support of the Government of Indonesia through the Indonesian Institute of Sciences, Bogor Botanic Gardens carried out an expedition during March-April 2013 to survey for a possible remnant population of $D$. cinereus on Mursala Island. After more than 2 weeks the team found D. cinereus in at least two localities. However, we found only three mature trees, and several seedlings that we believe to be of this species. According to local people $D$. cinereus is a species targeted for its timber, along with other dipterocarp species such as Dryobalanops aromatica, Shorea spp. and Dipterocarpus caudatus ssp. penangianus.

Bogor Botanic Gardens is now carrying out further studies on the genetic variability of $D$. cinereus and other dipterocarp species found on the island. With the collaboration of the local people we are also planning to collect the fruits of $D$. cinereus, for propagation and future restoration of the species in the wild. Mursala Island is currently managed as a protected forest by the local government but we recommend that it receives improved protection, through the Ministry of Forestry.

Yayan Wahyu C. Kusuma, Wihermanto and Rosniati A. Risna Center for Plant Conservation Bogor Botanical GardenIndonesian Institute of Sciences, Bogor, Indonesia. E-mail yayanwahyu@gmail.com

Peter S. Ashton Royal Botanic Gardens Kew, Richmond, UK

\section{From research to responsible advocacy: the Association for Tropical Biology and Conservation finds common ground in Aceh, Indonesia}

Dramatic losses of forest and biodiversity across the AsiaPacific region are a great cause for concern. The region's tropical ecosystems are under immense pressures, be it from conversion to exotic plantations in Indonesia and Malaysia or intense demand for wildlife products in Vietnam and China. The fragmentation and disturbance of natural vegetation by proliferating road networks and other infrastructures is seriously affecting many sensitive species, especially those that are slow-reproducing, largebodied or range-restricted. Such changes are already altering 
seed dispersal, pollination and other key forest processes, making it even more difficult to predict the future impacts of climate change.

In the face of such challenges, tropical ecologists face daunting pressures to answer not just fundamental questions about the distribution and biology of Asia-Pacific fauna and flora but many pressing practical questions as well-questions that require engaging in the pithy realities of conservation practice. With this in mind, the Asia-Pacific Chapter of the Association for Tropical Biology and Conservation held its 6th annual meeting in March 2013. Gathering under the theme Linking Biodiversity Science to Policy and Conservation Action, over 200 researchers from 25 nations met in Banda Aceh, in the far north of Sumatra, Indonesia.

Over four days more than 150 talks and posters highlighted cutting-edge issues in conservation and tropical biology. These were arranged within 13 symposia, such as Biogeography, Biodiversity and Bioinformatics of the Tropical Asian Flora, Species to Seascapes: Innovative Approaches to Managing Marine Ecosystems, and Transforming Conservation Science into Conservation Action. The Association's current President Lúcia Lohmann explained how her biogeographical studies of lianas could help untangle the complex history of tropical forests, and former President William Laurance spoke about growing pressures on biodiversity hotspots. Indian doctoral student Nandini Velho received the Outstanding Student Paper prize (From mosquito to Minister: malaria and the management of a tiger reserve in north-east India) and Manichanh Satdichanh from Lao PDR was awarded best Student Poster (Species composition of angiosperms in Phou Khao Khoauy National Park, Lao PDR).

In addition to the talks and posters seven workshops were run, by international experts, to enhance the capacity of regional scientists. These included training in Experimental Design and Data Analysis, Scientific Proposal Writing, SMART Conservation Software for Law Enforcement Monitoring, and Evolutionary Approaches to Biodiversity Science. In total, 27 fellowships were awarded for aspiring scientists and conservation researchers to attend these courses.

As researchers discussed the many challenges facing Asia-Pacific biodiversity and ecosystems, the local NGO community called stridently in the national press for the Association to take a formal position on the so-called Aceh Spatial Plan. Sentiments were running so high that over 70 local demonstrators gathered outside the conference venue on its opening night, urging the Association to act. Sumatra has suffered devastating forest loss and degradation in recent decades, with Aceh Province containing the largest surviving block of intact forest-and the only place where tiger, rhino, elephant and orang-utan still co-occur. The Plan will govern the fate of over 3 million ha of the
Province's forests and includes, in its present version, provisions to convert large expanses of forest to oil palm, pulpwood and paper plantations.

In the face of such urgency the Association elected to issue a formal statement - the Banda Aceh Declarationafter conferring with its Committee members, local NGOs and relevant members of the Aceh Government. The Declaration recommended that the Aceh Spatial Plan be based on the best scientific data available, and that it considers fully the environmental risks associated with the loss and degradation of ecological services that underpin Aceh's economy and the well-being of its citizens. It also stressed the need to enforce the law to halt ongoing illegal logging. The Declaration is an unprecedented achievement for Aceh because it is the first joint position that leading scientists, local conservation NGOs and the Government of Aceh have agreed upon. Such common ground should help these stakeholders as they engage in future debate and negotiations.

The Association for Tropical Biology and Conservation has historically had its greatest strength in Latin America but with recent annual conferences in Germany (2009), Bali (2010) and Tanzania (2011), the growth of its AsiaPacific Chapter, and forthcoming conferences in Australia (2014) and Cambodia (2015), it has become a truly global organization for advancing tropical research and conservation.

MatThew LinKIE Fauna \& Flora International, Cambridge, UK. E-mail matthew.linkie@fauna-flora.org

WILLIAM LAURANCE Centre for Tropical Environmental and Sustainability Science and School of Marine and Tropical Biology, James Cook University, Cairns, Queensland, Australia

Antony Lynam Wildlife Conservation Society, Global Conservation Program, Bronx, New York, USA

Lúcia LohmanN Universidade de São Paulo, Instituto de Biociências, Departamento de Botânica, São Paulo, Brazil

\section{Strong evidence that the West African chimpanzee is extirpated from Burkina Faso}

The Endangered West African chimpanzee Pan troglodytes verus is one of the most threatened subspecies of chimpanzee, with an annual decline of at least $4.7 \%$; populations in its eastern range have been particularly vulnerable to local extinctions. Côte d'Ivoire has experienced a 90\% population decrease over the past 20 years, and $P$. troglodytes verus is generally considered to be extirpated from Benin, Togo and Burkina Faso. Opinions in the literature are undecided, with inconsistent accounts and distribution maps. The 2003 IUCN Status Survey and 